\title{
Does Pecking Order Theory Apply to Firms in Brazil and the Pacific Alliance?
}

\author{
Renato Hideki Nakasato*, Wanderson Heideric Lizardo da Silva, Douglas Dias Bastos and Michele Nascimento Juca \\ Center of Applied Social Sciences, Mackenzie Presbiterian Univesity, Rua da Consolacao, 930 - Sao Paulo/SP, Brazil
}

${ }^{*}$ Corresponding author: Nakasato RH, Center of Applied Social Sciences, Mackenzie Presbiterian Univesity, Rua da Consolacao, 930 - Sao Paulo/SP, Brazil, Tel: +(11) 3091-7555; E-mail: nakasato@gmail.com

Received date: December 21, 2018, Accepted date: February 19, 2019, Published date: February 26, 2019

Copyright: (C) 2019 Nakasato RH, et al. This is an open-access article distributed under the terms of the Creative Commons Attribution License, which permits unrestricted use, distribution, and reproduction in any medium, provided the original author and source are credited.

\begin{abstract}
The purpose of this study is to test the application of pecking order theory (POT) to companies operating in Brazil and the countries that form the Pacific Alliance (Mexico, Chile, Peru, and Colombia). In order to do this, the methodology chosen is the one developed by Frank and Goyal, which aims to check if the company's capital structure follows a specific hierarchy based on capital cost. The sample consists of 255 listed companies operating in Brazil and 346 listed companies operating in Pacific Alliance countries between 2010 and 2016. The applied method is a pooled panel data regression model The results point out that the mentioned theory is more applicable to major corporations in Brazil but as well as to small firms in the Pacific Alliance countries. These findings are obtained based on the statistical significance of capital structure determinant market-to-book value ratio, for Brazilian companies, and at tangibility and profitability, in the case of Pacific Alliance companies.
\end{abstract}

Keywords: Capital structure; Pecking order; Panel data; Brazil; Pacific alliance; Capital structure determinants

\section{Introduction}

Corporate capital structure has been a major topic since the seminal papers by Modigliani and Miller [1-3]. However, its assumptions are grounded on the existence of a perfect market where: a) there are no corporate income taxes; b) arbitrage is not possible; c) there are no transaction costs; d) there are no bankruptcy costs; e) corporate financing capacities are unlimited; and f) there is no asymmetrical information, among other assumptions. Nevertheless, market reality takes heed of theories explaining the definition of ideal proportions and sources of corporate capital structures. Particularly noteworthy among them is the pecking order theory (POT).

Proposed by Myers [4] and Myers and Majluf [5], the POT establishes a financing hierarchy through which firms seek funding in the following order: internal (from operations); debt (taking out loans); and new equity (issuing shares). Since then, it has been tested empirically through studies (e.g., Helwege and Liang [6]; ShyamSunder and Myers [7]; Graham and Harvey [8]; Frank and Goyal [1]; Leary and Roberts [9]; Serghiescu and Vaidean [10]; Miglo [11]. These studies test POT in its weak, semistrong, and strong forms. According to Frank and Goyal [1], a semistrong or weak form focuses on internal sources and debt, in addition to issuing shares to some extent, while the strong form indicates that firms are funded internally and through debt.

There are also POT analysis studies focused on Latin America. The study by Medeiros and Daher [12] concluded that the tested theory is applicable to Brazilian corporations, in its weak form, noting that they seem closer to the strong POT form than their US counterparts. In turn, Perobelli and Famá [13] raised the issue of each corporation's specific characteristics and the economic contexts that surround them. They emphasize that capital structure choice is influenced by the specific attributes of each business, and the more profitable ones opt less for debt, while Bastos, Nakamura, and Basso [14] conclude that capital structure of corporations in Latin America is best explained by the POT.

Other than Brazil, countries in the Pacific Alliance (PA) have become particularly noteworthy in Latin America. This is a trading bloc that was formally established in June 6, 2012, in Chile, with its other founding members being Colombia, Mexico, and Peru; Costa Rica joined the group in 2013 (e.g., Romero [15]). Its purpose is to set up a free trade area and enhance economic integration among its members.

The countries belonging to this alliance are noteworthy for their more liberal economic leanings, compared to their Latin American neighbors. By 2015 , they reached a market deregulation level of $47 \%$, compared to only $35 \%$ over the same period for the members of South America's Mercosur trading bloc: Argentina, Uruguay, Paraguay, and Brazil (World Bank and World Integrated Trade Solutions, WITS [16]). Market deregulation levels or coefficients reflect trade links between a country and the rest of the world, measured by the ratio between the sum of its imports and exports in terms of its Gross Domestic Product (GDP) (Sarquis [17]).

As explained, the purpose of this study is to test the effective application of POT to non-financial corporations in Brazil and the PA countries, in addition to exploring the existence of possible differences between them. The comparison of the findings differs from other studies of this topic, as it moves further ahead with POT tests, striving to compare countries with different levels of market deregulation. The key question is thus: Does POT apply to firms in Brazil and the PA countries? Seeking answers, a pooled OLS regression model was used with data from 2010 to 2016 drawn from the Compustat database.

\section{Review of the Literature}

According to Modigliani and Miller [2,3], corporate capital structures indicate sources of financing, which may be internal or 
external. In their papers, the authors start out from the assumption that a perfect market exists to define their propositions on the irrelevance of the capital structure. However, in markets that are inefficient or conflictive, other theories tend to explain funding uptakes, with the most noteworthy being the POT and the trade-off theory (TOT).

POT claims that corporations choose funds through a hierarchy, first opting for internal funding, followed by debt papers, and finally issuing shares on the market. They prefer internal funding to external financing and new equity $[1,4]$.

Having noted that managers of major corporations assign higher priority to internal rather than external sources of funding, Donaldson [18] outlined a hierarchy for these sources. This theoretical trend was formally developed by Myers [4], who showed that corporate capital structure is the outcome of decisions that follow an order of preference when seeking funds.

Myers and Majluf [5] explain that asymmetric information between managers and external agents results in an adverse selection situation, as external agents have less information that might steer managers toward sources of funding that are the most appropriate for their purposes (signaling).

Brealey et al. [19] analyze the asymmetry of information between managers and investors, showing that corporations that are optimistic about the future raise funds through debt papers. Looking at two identical businesses, a firm with an upbeat view of its future investments will avoid financing through new equity, as the market will undervalue these shares, resulting in transfer of wealth from old shareholders to new investors who benefit from undervalued equity and positive investment projects. Consequently, the firm will instead issue debt papers. In contrast, a corporation with a gloomy view of its future investment projects will issue new equity precisely in order to share these losses with its incoming shareholders.

It is clear that the market feels that corporations issuing debt papers have profitable projects lined up, while firms issuing shares look askance at their future. This evidence has been confirmed empirically by $\mathrm{Wu}$ and Yeung [20].

The problem associated with adverse selection when issuing papers (debt and/or equity) was identified by Krasker [21], among others, noticing that investors view stock issues unfavorably. Internal funds are more frequently used as a way of minimizing information asymmetry between managers and investors.

More recently, Bharath and Pasquariello [22] suggested an information asymmetry index based on adverse selection measurements explored in the literature on market microstructures, aiming at testing the POT. This study underscores the importance of information asymmetry in capital structure formation, although its classic determinants (size, tangibility, Tobin's Q ratio, and profitability) and external sources of financing (return, stock volatility, and papers liquidity) also influence debt levels, buttressing the POT to some extent.

According to this theory, the financial behavior of corporations is led by the costs of their financing choices, probably functioning more effectively for businesses facing problems with information asymmetry when selecting sources of funding - for example, Frank and Goyal [1].

However, Shyam-Sunder and Myers [7], and Frank and Goyal [1] confirm the superiority of the POT for major corporations that are theoretically affected less by information asymmetry problems.
Denis and McKeon [23] believes that debt levels are defined by financial shortfalls/surpluses, as predicted by the POT. In general, businesses with financial deficits focus on reducing debt rather than shareholder remuneration. This consequently leads to the conclusion that the capital structure is not clearly defined, with no indebtedness goals, instead varying by investment needs.

The main idea behind the POT arises when managers choose a type of financing for investing in their business activities. They take many different factors into consideration, such as capital costs, market conditions, and shareholder interest. However, the most important factor is the impact of information asymmetry on the company image with its shareholders and credit market agents. Financing through new equity is a last resort and the worst choice for managers, due to possible underpricing that may adversely affect the business [4].

However, understanding the reasons for issuing shares is difficult. In some empirical studies, the POT found no support. The findings of Helwege and Liang [6] for firms going public from the mid-1980s onward suggest that the possibility of seeking outside financing is unrelated to insufficient internal funds. Besides, they suggest that access to the capital market does not follow a tiered funding source structure.

Similarly, Frank and Goyal [1] mention a predominance of new equity, particularly from the 1990s onward. The POT was actually quite feasible for major corporations during the 1970s and 1980s but then tapered off with the appearance of other capital structure determinants. The authors also note that financial deficits do not explain the preference for debt among all the firms in the sample, regardless of their size.

Fama and French [24] had already established a certain predominance for new equity, which would weaken the POT. The TOT and POT tests are ambiguous because short-term variations in investments are driven by debt, which reinforce the POT, despite a slow shift toward an optimal debt level, corroborating the TOT.

Still on the issue of new equity in the POT context, Dittmar and Thakor [25] argue that managers issue more shares to finance projects when investor objectives are aligned with their own goals; otherwise, there is a preference for debt. As a result, new equity is of secondary importance, when stock issues are overvalued. The authors do not refute the POT completely, but rather adapt it to specific situations.

Frank and Goyal [26] investigated which determinants really impact capital structures. In a survey covering the period between 1950 and 2003, debt level at market value is affected more strongly by the following factors:

- Tangibility: firms with more tangible assets tend to be more indebted, aligned with the POT;

- Profitability: more profitable businesses tend to have less debt, also compliant with the POT;

- Firm size: larger corporations (with more assets) tend to have more debt, leaning toward the TOT rather than POT;

- Market-to-book-value ratio: firms with higher market-to-bookvalue (MTB) ratios tend to have less debt, with both direct and indirect links to indebtedness supported by the POT.

Very similar results are found by Brito, Corrar, and Batistella [27]; Bastos, Nakamura, and Basso [14]; and Correa, Basso, and Nakamura [28] for Brazilian corporations. There is an inverse relationship between debt and the tangibility and profitability factors. Firm size is 
Page 3 of 8

directly related to debt, while MTB ratios barely hint at very vague links to debt levels. This evidence underpins a predominance of the POT in Brazil.

\section{Methods}

The sample addressed by this study encompasses listed companies in a variety of fields, excluding financial sectors and related areas, operating in Brazil and members of the PA like Mexico, Chile, Peru, and Colombia. Costa Rica joined this group only in 2013, so it is not included in the sample selected for this study. The economic and financial data was mined from the Compustat database, excluding firms with missing information (less than two consecutive observations) from this initial selection. The variables were then winsorized at $1 \%$ to eliminate outliers, resulting in a final sample of 255 firms operating in Brazil and 346 firms operating in the PA countries, except for Costa Rica (Mexico: 96 firms, Chile: 140 firms, Peru: 80 firms, and Colombia: 30 firms). The period studied is from 2010 to 2016.

In order to explore closer compliance with the POT in an explanation for corporate capital structures, its most aggregated model (eqn. (1)) is analyzed, with all the variables scaled by total assets. In the model, the firm assigns top priority to financing through debt, whenever its operating cash flow fails to keep pace with its investment decisions or dividend distributions: strong form of POT. New equity is issued only in last-ditch situations when debt would be extremely risky, or bankruptcy seems imminent: weak form (Shyam-Sunder and Myers [7]; Frank and Goyal [1]).

$$
D E F_{\mathrm{t}}=D I V_{\mathrm{t}}+I N V_{\mathrm{t}}+\Delta W C A P_{\mathrm{t}}-F C_{\mathrm{t}}=\Delta D_{\mathrm{t}}+\Delta E_{\mathrm{t}}
$$

Where:

$\mathrm{DEF}_{\mathrm{t}}=$ Operating cash flow deficit (or financial deficit in year $\mathrm{t}$ ),

$\operatorname{DIV}_{\mathrm{t}}=$ Dividends paid out in year $\mathrm{t}$,

$\mathrm{INV}_{\mathrm{t}}=\mathrm{Net}$ capital investment in year $\mathrm{t}$ (capital expenditures + increase in investments+acquisitions+other uses of funds - sales of fixed assets - sale of investment),

$\mathrm{WCAP}_{\mathrm{t}}=$ Variation in working capital in year $\mathrm{t}$ (variation in operating working capital+variation in cash and cash equivalents +variation in short-term debt),

$\mathrm{FC}_{\mathrm{t}}=$ operating cash flow after interest and tax (profits before exceptional items+depreciation and amortization+exceptional items and discontinued operations+deferred taxes+equity capital in net losses -earnings+other operating funds+earnings (losses) on sales of fixed assets and other investments),

$\mathrm{D}_{\mathrm{t}}=$ Issue of debt papers in year $\mathrm{t}$ (long-term debt issue - long-term debt reduction),

$\mathrm{E}_{\mathrm{t}}=$ issue of equity capital in year $\mathrm{t}$ (sale of common shares buyback stock).

The POT assumes that all financial deficit components are exogenous $[1,7]$. In the model proposed by Shyam-Sunder and Myers [7] (eqn. (2)), the variation in debt $(\Delta \mathrm{D})$ must be explained by a single variable, construed as an operating cash flow deficit (DEF) aggregate variable. Under the POT, shares are issued through initial public offerings (IPOs) in only extreme situations.

$$
\Delta D_{\mathrm{it}}=\alpha+\beta D E F_{\mathrm{it}}+e_{\mathrm{it}}
$$

Where:

Dit=Debt issued by company i in year $\mathrm{t}$ (long-term debt issue long-term debt reduction),

$\alpha=$ Linear coefficient,

$\beta=$ Angular coefficient,

$\mathrm{DEFt}=$ Operating cash flow deficit of company $i$ in year $t$,

eit=Error term of company $\mathrm{i}$ in year $\mathrm{t}$.

In eqn. (2), the POT expects that $\alpha=0$ and $\beta=1$. This shows that the issue of debt papers is directly proportional to the funding shortfall, with no room for issuing shares. In the weak POT form that allows new equity, $\alpha$ may be different from 0 and $\beta$ less than but still close to 1. Statistical rejection of its strong and weak forms results in rejection of the POT.

In turn, a breakdown form of the equation is used in the study by Frank and Goyal [1] to ascertain whether the data fit the aggregate model. This also helps to verify the behavior of each compound variable in the DEF variable and its impact on the $\triangle \mathrm{D}$. What is important for the POT is the DEF. Any unit increase in any eqn. (1) component must have the same impact on the $\Delta \mathrm{D}$ (eqn. (3)).

$$
\Delta D_{\mathrm{it}}=\alpha+\beta_{\mathrm{DIV}} D I V_{\mathrm{t}}+\beta_{\mathrm{INV}} I N V_{\mathrm{t}}+\beta_{\mathrm{WCAP}} \Delta W C A P_{\mathrm{t}}-\beta_{\mathrm{FC}} F C_{\mathrm{t}}+e_{\mathrm{it}}
$$

Where:

$\mathrm{D}_{\mathrm{it}}=$ Debt issued by company $\mathrm{i}$ in year $\mathrm{t}$ (long-term debt issue long-term debt reduction),

$\alpha=$ Linear coefficient,

$\beta=$ Angular coefficient,

DIV $_{\mathrm{t}}=$ Dividends paid in year $\mathrm{t}$,

$\mathrm{INV}_{\mathrm{t}}=$ Net capital investment in year $\mathrm{t}$ (capital expenditure+increase in investments+acquisitions+other uses of funds - sales of fixed assets - sale of investment),

$\mathrm{WCAP}_{\mathrm{t}}=$ Variation in working capital in year $\mathrm{t}$ (variation in operating working capital+variation in cash and cash equivalents +variation in short-term debt),

$\mathrm{FC}_{\mathrm{t}}=$ Operating cash flow after interest and tax (profits before exceptional items+depreciation and amotization+exceptional items and discontinued operations+deferred taxes+equity capital in net losses - earnings+other operating funds+earnings (losses) on sales fixed assets and other investments),

\section{$e_{i t}=$ Error term of company $i$ in year $t$.}

So the POT hypothesis is thus that: bDIV b1NV bWCAP bFC 1. If this hypothesis is correct, then the aggregate model in eqn. (1) is justified [1]. However, it must be stressed that the traditional debt equation explains indebtedness levels (stock variable), while the POT equation explains change (flow variable) rather than debt level. As changes are not correlated from year to year, corporate debt levels may be analyzed through the first difference $(\Delta)$ (eqn. (4)).

$$
\begin{aligned}
& \Delta D_{\mathrm{i}}=\alpha+\beta_{\mathrm{TANG}} \Delta T A N G_{\mathrm{i}}+\beta_{\mathrm{MB}} \Delta M B_{\mathrm{i}}+\beta_{\mathrm{REC}} \Delta R E C_{\mathrm{i}}+\beta_{\mathrm{LUCR}} \Delta L U C R_{\mathrm{i}} \\
& +\beta_{\mathrm{DEF}} D E F_{\mathrm{i}}+e_{\mathrm{i}} \\
& \text { (4) }
\end{aligned}
$$

$\mathrm{D}_{\mathrm{i}}=$ Debt issued by company i (long-term debt issue - long-term debt reduction), 
Citation: Nakasato RH, da Silva WHL, Bastos DD, Juca MN (2019) Does Pecking Order Theory Apply to Firms in Brazil and the Pacific

Page 4 of 8

$\alpha=$ Linear coefficient,

$\beta=$ Angular coefficient,

TANG $_{\mathrm{i}}=$ Variation in tangible assets of company $\mathrm{i}$,

$\mathrm{MB}_{\mathrm{i}}=$ Variation in market-to-book-value ratio of company i (market value/book value),

$\mathrm{REC}_{\mathrm{i}}=$ Variation in sales of company $\mathrm{i}$ (sales log),

$L_{U C R_{i}}=$ Variation in profitability of company $i$,

$D F_{i}=$ Deficit in operating cash flow of company $i$,

$e_{i}=$ Error term of company $i$.

Eqn. (4) is a multiple linear regression with some variables added to the $\Delta \mathrm{D}$ model in order to identify the financial leverage level of a firm. From the standpoint of testing the POT, the most important conventional variable is tangibility (T) [1]. Firms with low-growth assets make the heaviest use of indebtedness in order to bridge their financial shortfalls [29]. As noted by Harris and Raviv [30], highervalue firms with few tangible assets are subject to asymmetric information problems, meaning that they are expected to opt for longterm debt. Companies with few tangible assets tend to build up more debt in order to underwrite their activities, leaving them more heavily leveraged over time. As tangible assets may be used as collateral for debt, it is forecast that $\beta \mathrm{T}>0$ [1].

In contrast, firms with high MTB ratios are viewed as endowed with ample growth potential [1]. Stock prices rise before new shares are issued and drop afterward, with the market believing that they intended to underwrite fresh investments [30]. This means that heavily indebted firms may curtail their new investment opportunities, leading to the expectation that $\beta \mathrm{MTB}<0$.

Major corporations are generally more diversified and less likely to file for bankruptcy [31]. They are able to finance their activities at low cost, with proportionately higher indebtedness, leading to a forecast of $\beta L S>0$.

Finally, profits generated and the amount of income that can be retained by firms are important factors shaping their capital structures. This means that profitable businesses are heavily leveraged [31], whereby it is expected that $\beta \mathrm{P}<0$.

In empirical terms, it is appropriate to stress that the aggregate deficit model (eqn. (2)) was tested by Shyam-Sunder and Myers [7] and Frank and Goyal [1], while the breakdown deficit model (eqn. (3)) and the indebtedness level variation model (eqn. (4)) were used only by Frank and Goyal [1].

\section{Results and Discussion}

Table 1 presents the descriptive statistics, showing that mean longterm debt (D) reaches $19.4 \%$ for firms in Brazil, compared to $16.4 \%$ for companies in the PA countries. The mean financial deficit (DEF) and dividends paid out are similar for both groups, together with negative net working capital (WCAP), which is lower for Brazilian firms $(-0.026)$. Mean long-term investments (INV) are slightly higher for PA firms at $4.7 \%$ of total assets. Finally, operating cash flows (CF) are also slightly higher for the PA at $6.7 \%$ of total assets. These figures do not indicate any noteworthy variations between firms operating in Brazil and those in the PA countries.

\begin{tabular}{|c|c|c|c|c|c|}
\hline \multicolumn{6}{|c|}{ Brazil } \\
\hline Variables & Observations & Mean & Standard Deviation & Minimum & Maximum \\
\hline D & 1,743 & 0.194 & 0.152 & 0 & 0.505 \\
\hline DEF & 1,015 & 0.006 & 0.116 & -0.264 & 0.272 \\
\hline DIV & 1,119 & 0.032 & 0.037 & 0 & 0.132 \\
\hline WCAP & 1,721 & -0.026 & 0.194 & -0.605 & 0.348 \\
\hline INV & 1,518 & 0.042 & 0.037 & 0 & 0.137 \\
\hline $\mathrm{CF}$ & 1,744 & 0.054 & 0.083 & -0.131 & 0.21 \\
\hline \multicolumn{6}{|c|}{ Pacific Alliance } \\
\hline Variables & Observations & Mean & Standard Deviation & Minimum & Maximum \\
\hline D & 2,351 & 0.164 & 0.134 & 0 & 0.432 \\
\hline DEF & 1,495 & 0.004 & 0.089 & -0.195 & 0.203 \\
\hline DIV & 1,563 & 0.033 & 0.035 & 0 & 0.136 \\
\hline WCAP & 2,317 & -0.005 & 0.106 & -0.294 & 0.204 \\
\hline INV & 2,242 & 0.047 & 0.04 & 0 & 0.147 \\
\hline $\mathrm{CF}$ & 2,349 & 0.067 & 0.059 & -0.032 & 0.2 \\
\hline
\end{tabular}


Citation: Nakasato RH, da Silva WHL, Bastos DD, Juca MN (2019) Does Pecking Order Theory Apply to Firms in Brazil and the Pacific

Table 1: Descriptive statistics.

Table 2 presents the findings for issuing long-term debt papers, with the operating cash flow deficit (or financial deficit) as an independent variable, as shown in eqn. (2). The ( $\alpha$ ) constant is close to zero and not statistically significant for the entire sample, in contrast to the financial deficit (DEF), which is statistically significant for the entire sample at 0.244 for Brazil and 0.203 for the PA, with an adjusted R2 at 0.081 and 0.045 for Brazil and the PA, respectively. This indicates that the POT is slightly more robust for firms operating in Brazil. These figures indicate that firms generally issue shares to a greater extent, with fewer debt papers, thus indicating the weak form of POT. The worst results for this theory were found in Peru and Colombia, underscoring the importance of new equity for these countries. Frank and Goyal [1] found a financial deficit of 0.152 and an adjusted R2 of 0.046 for US corporations between 1990 and 1998, for the total sample in terms of gross debt papers issued, similar to this study.

\begin{tabular}{|c|c|c|c|c|c|c|}
\hline & Brazil & Pacific Alliance & Mexico & Chile & Peru & Colombia \\
\hline \multirow[t]{2}{*}{ Constant } & 0 & -0.001 & -0.005 & -0.001 & 0 & 0.002 \\
\hline & $(0.003)$ & $(0.002)$ & $(0.005)$ & $(0.003)$ & $(0.004)$ & $(0.006)$ \\
\hline \multirow[t]{2}{*}{ DEF } & $0.244^{* \star *}$ & $0.203^{\star \star \star}$ & $0.211^{\star \star \star}$ & $0.210^{\star \star *}$ & $0.167^{\star \star *}$ & $0.165^{\star *}$ \\
\hline & $(0.025)$ & $(0.024)$ & $(0.061)$ & $(0.033)$ & $(0.05)$ & $(0.071)$ \\
\hline Observations & 1.015 & 1.494 & 298 & 686 & 351 & 158 \\
\hline R-squared & 0.081 & 0.045 & 0.037 & 0.055 & 0.031 & 0.032 \\
\hline No Firms & 255 & 346 & 96 & 140 & 80 & 30 \\
\hline
\end{tabular}

Table 2: Aggregate model by finance deficit.

Table 3 shows the results for the breakdown model, as presented in eqn. (3). In general, the coefficients were low for all the variables, yet again undermining the strong SPOT form. In Brazil as well as the PA, dividends paid out (DIV) seem to have no influence on the formation of financial deficits, except in Peru (0.303). The net working capital (WCAP) was a positive and statistically significant ratio for both Brazil and the PA (0.201 and 0.173, respectively). Long-term investments (INV) were also positive and statistically significant for both Brazil and the PA (0.329 and 0.362, respectively). With the POT, a high positive ratio is expected with net working capital and debt as well as long-term investments and debt. The evidence presented here was not robust enough for the POT. It is timely to note that the TOT also indicated a positive ratio. In contrast, a negative ratio is expected for the operating cash flow (CF) and debt, with the figures for Brazil and the PA being -0.126 and -0.174 , respectively. The coefficients for the POT were low. These figures are very similar to those found by Frank and Goyal [1] for gross debt paper issues in the total sample of US corporations.

\begin{tabular}{|c|c|c|c|c|c|c|}
\hline & Brazil & Pacific Alliance & Mexico & Chile & Peru & Colombia \\
\hline \multirow[t]{2}{*}{ Constant } & -0.006 & -0.005 & -0.009 & -0.006 & 0.002 & -0.018 \\
\hline & $(0.005)$ & $(0.004)$ & $(0.015)$ & $(0.006)$ & $(0.007)$ & $(0.012)$ \\
\hline \multirow[t]{2}{*}{ DIV } & 0.147 & 0.061 & 0.183 & -0.154 & $0.303^{\star * *}$ & -0.207 \\
\hline & $(0.103)$ & $(0.079)$ & $(0.209)$ & $(0.119)$ & $(0.104)$ & $(0.301)$ \\
\hline \multirow[t]{2}{*}{ WCAP } & $0.201^{\star \star *}$ & $0.173^{\star \star \star}$ & $0.338^{* * *}$ & $0.140^{\star \star *}$ & $0.131^{\star \star \star}$ & $0.185^{* *}$ \\
\hline & $(0.019)$ & $(0.022)$ & $(0.06)$ & $(0.028)$ & $(0.05)$ & $(0.074)$ \\
\hline \multirow[t]{2}{*}{ INV } & $0.329^{\star \star *}$ & $0.362^{* * *}$ & $0.396^{\star \star}$ & $0.389^{\star \star \star}$ & $0.345^{\star \star *}$ & $0.438^{\star *}$ \\
\hline & $(0.085)$ & $(0.059)$ & $(0.163)$ & $(0.084)$ & $(0.119)$ & $(0.173)$ \\
\hline $\mathrm{CF}$ & $-0.126^{* *}$ & $-0.174^{\star \star \star}$ & $-0.259^{*}$ & -0.074 & $-0.319^{* * *}$ & 0.087 \\
\hline
\end{tabular}


Citation: Nakasato RH, da Silva WHL, Bastos DD, Juca MN (2019) Does Pecking Order Theory Apply to Firms in Brazil and the Pacific

Page 6 of 8

\begin{tabular}{|l|l|l|l|l|l|l|}
\hline & $(0.054)$ & $(0.051)$ & $(0.15)$ & $(0.087)$ & $(0.08)$ & $(0.14)$ \\
\hline Observations & 1.015 & 1.494 & 298 & 686 & 351 & 158 \\
\hline R-squared & 0.11 & 0.054 & 0.104 & 0.06 & 0.056 & 0.073 \\
\hline No Firms & 255 & 346 & 140 & 80 & 30 \\
\hline $\begin{array}{l}\text { Model estimated through eqn. (3). Dependent variable: Variation in gross long-term debt. Standard error in brackets. *** }{ }^{* *} \text { and * indicate significance levels of 1\%, 5\% } \\
\text { and 10\% respectively. Source: Prepared by the authors }\end{array}$
\end{tabular}

Table 3: Breakdown model for financial deficit.

Frank and Goyal [1] warn of possible differences in POT results, related to firm size. As the POT is granted on information asymmetry, small firms with ample growth opportunities have strongly asymmetric information, allowing their capital structure to be explained by the POT. However, Shyam-Sunder and Myers [7] and Frank and Goyal [1] noted the superiority of the POT for major corporations that are theoretically less affected by problems arising from information asymmetry. Table 4 portrays financial deficits (DEF) by dividing the sample into smaller and larger businesses. Among Brazilian firms, the findings suggest that the POT is slightly better adapted to larger businesses (0.289) compared to their smaller counterparts (0.211). On the other hand, in the PA, the POT prevails for smaller companies (0.245), as expected by its theoretical grounds.

\begin{tabular}{|c|c|c|c|c|}
\hline & \multicolumn{2}{|l|}{ Brazil } & \multicolumn{2}{|l|}{ Pacific Alliance } \\
\hline & Smaller Firms & Larger Firms & Smaller Firms & Larger Firms \\
\hline \multirow[t]{2}{*}{ Constant } & $-0.009^{*}$ & $0.007^{\star *}$ & -0.003 & 0 \\
\hline & $(0.005)$ & $(0.003)$ & $(0.003)$ & $(0.002)$ \\
\hline \multirow[t]{2}{*}{ DEF } & $0.211^{* * *}$ & $0.289^{\star \star *}$ & $0.245^{\star \star \star}$ & $0.155^{\star * *}$ \\
\hline & $(0.038)$ & $(0.035)$ & $(0.033)$ & $(0.034)$ \\
\hline Observations & 414 & 601 & 733 & 761 \\
\hline R-squared & 0.068 & 0.1 & 0.067 & 0.026 \\
\hline
\end{tabular}

Table 4: Aggregate model for financial deficits by firm size.

The traditional debt equation explains indebtedness levels (stock variable), while the POT equation explains change (flow variable) rather than debt level. As changes are not correlated from year to year, corporate debt levels may be analyzed through the first difference $(\Delta)$, as shown in eqn. (4). Table 5 presents a positive ratio between debt and tangibility (TANG) that is statistically significant for the PA (0.170), as forecast by the POT. For Brazilian firms, an inverse ratio was found between the market-to-book-value $(\mathrm{MB})$ and debt $(-0.063)$, also compliant with the POT. Measured by sales, firm size is linked positively and significantly to debt in Brazil $(0.031)$ as well as the PA
(0.051), while the expected ratio is negative under the POT, as larger firms are faced by less information asymmetry, with lower new equity costs making this option preferable to debt. The direct link between size and indebtedness is foreseen in the TOT. For PA firms, profitability was negative and statistically significant $(-0.289)$, aligned with the POT, in contrast to Brazil, where this link was positive and significant (0.162), aligned with the TOT. Finally, financial deficits (DEF) were higher in Brazil than in the PA (0.262 and 0.181, respectively), indicating that the POT is more appropriate for Brazil, although still quite irrelevant (low coefficient, well below one).

\begin{tabular}{|l|l|l|l|l|l|l|}
\hline & Brazil & Pacific Alliance & Mexico & Chile & Peru & Colombia \\
\hline Constant & -0.001 & -0.002 & -0.008 & -0.002 & 0 & -0.002 \\
\hline & $(0.002)$ & $(0.002)$ & $(0.006)$ & $(0.003)$ & $(0.004)$ & $(0.005)$ \\
\hline STANG & 0.009 & $0.170^{* *}$ & -0.007 & $0.283^{* *}$ & $0.135^{* *}$ & 0.047 \\
\hline
\end{tabular}


Citation: Nakasato RH, da Silva WHL, Bastos DD, Juca MN (2019) Does Pecking Order Theory Apply to Firms in Brazil and the Pacific Alliance?. Bus Eco J 10: 386. doi:10.4172/2151-6219.1000386

Page 8 of 8

empírico considerando fatores macroeconômicos e institucionais. Rev de Administração Mackenzie 10: 47-77.

15. Romero AMS (2014) Aliança do pacífico: soberania nacional e estratégia de integração na América Latina. Conjuntura Glob 3: 89-98.

16. World Bank, GDP (Current US Dollars).

17. Sarquis SJB (2011) Comércio internacional e crescimento econômico no Brasil. Fundação Alexandre de Gusmão, Brasília, Brasil.

18. Donaldson G (1961) Corporate debt capacity: a study of corporate debt policy and the determination of corporate debt capacity, Beard Books Press, Washington.

19. Brealey R, Myers S, Allen F (2008) Principles of Corporate Finance. Irwin, Mc Graw Hill.

20. Wu X, Yeung CKA (2012) Firm growth type and capital structure persistence. J Bank Financ 36: 3427-43.

21. Krasker W (1986) Stock price movements in response to stock issues under asymmetric information. J Financ 41: 93-105.

22. Bharath ST, Pasquariello P, Wu G (2009) Does asymmetric information drive capital structure decisions? Rev Financ Stud 22: 3212-3243.

23. Denis DJ, McKeon SB (2012) Debt financing and financial flexibility evidence from proactive leverage increases. Rev Financ Stud 25: 1898-1929.
24. Fama EF, French KR (2002) Testing trade-off and pecking order predictions about dividends and debt. Rev Financ Stud 15: 1-33.

25. Dittmar AK, Thakor A (2007) Why do firms issue equity? J Financ 62: 1-54.

26. Frank MZ, Goyal VK (2009) Capital structures decisions: Which factors are reliably important? Financ Manage 38: 1-37.

27. Brito GAS, Corrar LJ, Batistella FD (2007) Fatores determinantes da Estrutura de Capital das maiores empresas que atuam no Brasil. Rev de Contabilidade e Finanças da USP 43: 9-19.

28. Correa CA, Basso LFC, Nakamura WT (2013) A estrutura de capital das maiores empresas brasileiras: Análise empírica das teorias de pecking order e trade-off, usando panel data. Rev de Administração Mackenzie 14: 106-133.

29. Iquiapaza RA, Amaral HF, Araújo MSB (2008) Testando as previsões da pecking order theory no financiamento das empresas brasileiras: uma nova metodologia. Rev de Administração Mackenzie 9: 157-183.

30. Harris M, Raviv A (1991) The theory of capital structure. J Financ 46: 297-355.

31. Titman S, Wessels R (1988) The determinants of capital structure choice. J Financ 43: 1-19. 